41. Rogozhin A.I. Sotsialisticheskaya zakonnost v USSR v period provedeniya Velikoy Oktyabrskoy sotsialisticheskoy revolyutsii i v period grazhdanskoy voyny i inostrannoy voennoy interventsii : dis. ... kand. yurid. nauk: 12.00.01. Kharkov, 1950. $320 \mathrm{~s}$.

42. Rogozhin A.I. Ocherk istorii sotsialisticheskoy zakonnosti USSR $\vee$ period inostrannoy voennoy interventsii i grazhdanskoy voyny. Kharkov : Izdatelstvo Kharkovskogo gosudarstvennogo universiteta im. A.M.Gorkogo, 1963. $120 \mathrm{~s}$.

43. Skrypnyk M.O. Vybrani tvory / Uporjad. : I. F. Kuras (ker.) ta in. K. : In-t polit. doslidzh., 1991. 617 s.

44. Slavin N.G. Sud i novaya ekonomichskaya politika // Yezhenedelnik Sovetskoy Yustitsii. 1922. № 1 . S. $6-7$.

45. Strogovich M.S. Kurs sovetskogo ugolovnogo protsessa. Tom 1. Osnovnye polozheniya nauki sovetskogo ugolovnogo protsessa. M. : «Nauka», 1968. $468 \mathrm{~s}$.

46. Stuchka P.I. Klassovyy ili demokraticheskiy sud // Pravda. 1917. № 185. S. 2.;

47. Stuchka P.I. Proletarskoe pravo // Oktyabrskiy perevorot i diktatura proletariata. Sb. st. 1919. S. 210-220;

48. Sud i pravosudie v SSSR: uchebnik. / pod. red. Galkina B. A. M. : Yuridicheskaya literatura, 1981. $320 \mathrm{~s}$.

49. Suslo D.S. Istoriya sudu Radyanskoï Ukraïni: (1917-1967 rr.). K. : Vid-vo pri Kiïvskomu un-ti, 1968. $233 \mathrm{~s}$;

50. Titov Yu.P. Pervye normativnye akty o sovetskikh revolyutsionnykh tribunalakh // Sovetskoe gosudarstvo i pravo. 1990. № 1. S. 119-124.

51. Undrevich V.S., Kareva M. P. Proletarskaya revolyutsiya i gosudarstvennyy apparat : (Ocherk istorii borby za gosapparat v 1917-1918 gg.) M. : Vlast Sovetov, 1935. $142 \mathrm{~s}$.

52. Usenko I.B. Pozasudova represija. Jak ce pochynalosj (z istoriji orghaniv derzh. bezpeky) // Komunist Ukrajiny. 1990. № 2. S. 43-53

53. Khmelnitskiy A.I. Krasnoe pravo i krasnyy sud (publichnaya lektsiya). Odesa: Vseukr. Izd-vo, 1921. $20 \mathrm{~s}$.

54. Cheltsov-Bebutov M.A. Prestuplenie $\mathrm{i}$ nakazanie $\mathrm{v}$ istorii $\mathrm{i} v$ sovetskom prave. Kharkov: Yuridicheskoe izd-vo, 1925. $111 \mathrm{~s}$.

Статтю подано до редколегії 26.03.2019 р.

УДК 94(477)«1985/1991»:394:316.342.6

DOI: https://doi.org/10.31652/2411-2143-2019-28-109-113

\title{
Олег Коваль
}

Вінницький державний педагогічний університет імені Михайла Коцюбинського, аспірант (Україна)

\section{Трансформація історико-фрілософських уявлень про повсякдення в зарубіжній історіографії}

Анотація. $у$ статті узагальнюються історико-фрілософрські підходи та їх трансформації у розгляді повсякдення в західній історіографрії. Розкривається важливість розуміння відмінностей песимістичного, френоменологічного, екзистенціального, прагматичного й інструментального, герменевтичного та семантичного підходів, концепції соціального становлення. Наголошується на важливості ролі цих підходів в становленні вітчизняної школи дослідження історії повсякдення. Пропонується розуміння трансформації уявлень про повсякдення через призму аналізу основних праць в рамках даних наукових течій.

Ключові слова: повсякдення, історія повсякдення, поліпарадигмальність, френоменологія, прагматизм, екзистенціалізм, герменевтика, соціальне становлення.

Інституціоналізація історії повсякдення, як на заході, так і в пострадянських країнах, зокрема в Україні, відбулася в періоди історичних зламів, коли динаміка суспільних перетворень вщент руйнувала існуючі концепції розуміння історико-політичної реальності, законів змін в ній, інтерпретації накопичених даних. Такі стрімкі перетворення в рамках суспільств не могли не мати відгук в фрілософрсько-історичному середовищі. Дослідження повсякдення в рамках німецької історіографрії в середині XX ст. було проявом бунту проти “традиціоналізму", яскравим прикладом системної кризи історичної науки. Приблизно в такому ж конфрліктологічному руслі, протиставлення макро-мікро, позитивізму-френоменології, детермінізму-екзистенціалізму відбулася інституціоналізація історії повсякдення в інших західних країнах: Об’єднаному 


\section{Наукові записки ВДПУ ім. М.М. Коцюбинсъкого}

Королівстві, Франції, США і т.д. Проте, аналізуючи праці О. Коляструк, С. Дровозюка, В. Головка, О. Удота, Н. Тригуба, Т. Заболотної та інших вітчизняних істориків, ми можемо прослідкувати не протиставлення традиційного і нового, а їх поєднання та взаємопроникнення в максимально різноманітних формах. Все це змушує нас по-новому переглянути існуюче, детерміноване західною традицією, розуміння формування інтересу до повсякдення і спробувати знайти внутрішні течії парадигмальних зрушень, які непомітно змінювали уявлення наукової спільноти про повсякдення та його роль в історичному процесі.

Метою статті $\epsilon$ аналіз особливості уявлень про повсякдення в історичному вимірі та розкриття процесу трансформації розуміння повсякдення у контексті аналізу західної історіографії.

Поряд із представниками школи Анналів, таких як М. Блок, Л. Февр, Ф. Бродель, Ж. Дюба та їх сучасними послідовниками (А. Гуревич, Ю. Безсмертний та Ю. Лотман) слід відзначити вагомий внесок в дослідження феномену повсякдення Г. Зіммеля, Е. Гуссерля, М. Хайдеггера, Ч. Пірса і У. Джеймса, Ж. Сартра і А. Камю, Е. Фромма, П. Штомпки.

Так, німецький фрілософ Г. Зіммель у своїх працях приділяє увагу повсякденню, що виступає в ролі рутини, яка протистоїть пригодам [4, с. 322-337]. Тобто автор продовжує песимістичну лінію розуміння повсякденного життя людини, яка фрормується в добу Відродження, починаючи з праць М. Монтеню та продовжуючи уявленнями С. К'єркегера та А. Шопенгауера.

Повсякдення - це сфрера з якої потрібно вириватися, яка $є з$ однієї сторони природною для людини, а з іншої подавлює ії̈ волю [4, с. 331].

Проте уже на початку XX ст. відбувається переосмислення ролі людини в історичному бутті. Вагомий внесок в зміну уявлень про повсякденності здійснив Е. Гуссерль, засновник Нової філософії в західній традиції. Згідно з вченням німецького фрілософра, повсякдення виступає в ролі окремого, відмінного від інших форм, буття людської реальності. За френоменологією Е. Гуссерля, повсякденне життя $є$ універсальним смислом, для якого характерні такі ознаки як внутрішня впорядкованість та власний когнітивний смисл.

Повсякдення - це та універсальна реальність, яка притаманна для всіх людей, при цьому в ній індивіди виступають в ролі суб'єктів, життя яких базується на основі природних установок. Оскільки проживання, переживання прожитого можливе тільки в рамках суб'єкта, його досвіду, то і сама повсякденна реальність отримує його властивості, основною з яких є її суб'єктивність в рамках свідомості окремо взятого індивіда [2, с. 134-137].

При цьому френоменологія повсякдення не акцентує увагу на життєвих практиках, матеріальних благах чи індивідуальних установках. Науковець повинен бачити не матеріальний предмет, чи діяльність людини, а концептуальні основи цього матеріального предмету, як пише сам Е. Гуссерль «побачити в столі можливість до буття, як стіл».

Традиції Е. Гуссерля продовжив у своїх працях М. Хайдеггер. Він першим проставив межі буття повсякдення, яке виступає в ролі не наукового та не історичного простору існування особи. Повсякдення - це сукупність рутинних повторюваних дій, які не пов'язані із самоосмисленням [7]. Філософ вважає це нижчою формою людської реальності, для нього повсякдення виступає в ролі буття, яке подавлює творчі пориви людини.

М. Хайдеггер розрізняє одні і ті ж дії в залежності від ступеня їх осмисленості та мети [7]. Для більшої наочності наведемо приклад: наукова дискусія і буденна розмова. Для першої притаманна осмисленість дій ії̈ суб'єктів і чітко окреслена ціль - вона може носити як безпосередньо вузький предметний характер, так і концептуальний. В той час як буденна розмова є випадковою дією за участі суб'єктів, які не переслідують конкретної цілі.

Власне такий погляд на повсякдення є достатньо суперечливим. Якщо за Е. Гуссерлем науковець має знайти внутрішні механізми, фееномени, які б пояснили повсякденну діяльність людини, то М. Хайдеггер відкидає їх наявність в повсякденному житті і прагне шукати їх за межами повсякдення.

А відповідно до цього можна вважати, що уявлення М. Хайдеггера про повсякдення $€$ ідеологізацією з негативним відтінком, в системі якої відбувається підміна поняття повсякдення рутиною, яка виступає складовою першого, але не заміщує його.

В працях вітчизняних авторів прослідковується певний вплив прагматизму (В. Даниленко, В. Марочко), який на відміну від феноменології, яка шукає суб'єктивну сторону людської повсякденної реальності, намагається знайти об'єктивне пояснення щоденної поведінки людини.

Ч. Пірс, вказує, що свідомість - це досвід перебування людини в світі, а людська діяльність - це пошук власної вигоди [5, с. 25]. Тобто людина діє на основі власного досвіду виходячи із пошуку користі. При цьому будь-яка діяльність $є$ корисливою і виходить із системи цінностей людини. У. Джеймс вважає, що повсякдення проявляється в прагматичних діях 


\section{Серія: Iсторія. - 2019.- Bun. 28.}

індивіда [5, с. 32-33]. Тобто, це не ірраціональна поведінка, а осмислена і спрямована діяльність на отримання певного результату. Виходячи із нашого попереднього прикладу порівняння наукової дискусії та буденної розмови за даною концепцією вони обидві можуть виступати раціональними діями, якщо учасники комунікації усвідомлюють яку вигоду вони можуть отримати в результаті такої взаємодії.

Д. Дьюї (представник течії інструменталізму) в певній мірі продовжує думку прагматиків, оскільки основним орієнтиром повсякденної діяльності для нього виступає, як і для Ч. Пірса досвід. Проте він акцентує увагу на тому, що світ повсякдення нестабільний, дії людей непередбачувані, тому індивіду потрібна максимальна концентрація духовних й інтелектуальних здібностей [5, с. 33]

Особливу роль в дослідженні історії повсякдення слід приділити екзистаціоналістам, теоретичні концепції котрих знайшли і продовжують знаходити особливе відображення в сучасній історіографрії України. Так, для представників даного напрямку повсякдення виступає не тільки в формі рутинних повторювальних процесів, але й переживання, невдачі та пристрасті: смерть, сором, страх, любов і т.д.

Ж. Сартр вважає, що людина несе повну відповідальність за своє життя, самостійно приймаючи рішення в повсякденні. При цьому не існує умов, при яких людина була б позбавлена суб'єктності в своєму житті, в незалежності від їі статі, віку, місця проживання, статус і ролі в суспільстві. Дане уявлення про повсякденність приводить науковця до концепції абсолютної свободи і самотності людини [6, с. 78]. При цьому слід зауважити, що Ж. Сартр не заперечує наявність зовнішніх, по відношенню до індивіда, стимулів, але особа здатна, як прийняти умови, так і відкинути їх, наприклад, ухилення від мобілізації під час військових дій, відмова від традиційної освіти. Можна погодитись про наявність певної свободи людини, проте Ж. Сартр упускає особливості первинної та вторинних соціалізації, цінності, які безумовно формуються за межами свідомості окремо взятої людини.

А. Камю також продовжує думки Ж. Сартра, при цьому науковець не апелює до абсолютної відповідальності людини за ії життєві процеси, але вказує на її домінантну роль. Картина повсякдення його сучасників бачиться для фрілософра сукупністю абсурдних i необдуманих характеристик [6, с. 78].

Представник фрранкфуртської школи Е. Фромм у своїй праці «Мати чи бути?» розкриває крос культурні відмінності розуміння свого повсякденного життя в різних частинах світу. Філософр ділить усі наявні суспільства на ті, в яких буття відбувається за рахунок привласнення («мати») i ті, в яких воно відбувається в процесі проживання («бути»). [3].

Слід зауважити, що праця була написана після завершення Другої світової війни, в якій фрілософр намагався знайти джерело виникнення в західній цивілізації причин, які привили б технологічно високорозвинуті капіталістичні суспільства до світових війн в XX ст. В своєму аналізі Е. Фромм виходив із концептуальних основ повсякденного життя людини і на основі теоретичного аналізу сприйняття реальності, розуміння себе в даній реальності запропонував класифікацію суспільств: ті в яких переважає тип сприйняття через «мати» i ті, в яких через «бути». [3].

Робота Е.Фромма «Мати чи бути?» має вагоме значення для історіографії, оскільки це одна 3 перших робіт філософсько-історичного спрямування, яка вказує на залежність макропроцесів від мікро.

Особливу вагу для дослідників радянської доби становлять праці Г. Гадамера, який розглядає повсякдення через призму передачі досвіду між поколіннями. Проте фрілософр вважає, що попри прагнення батьків застерегти своїх дітей від помилок за допомогою власного досвіду, в результаті діти не отримують потрібного повсякденного знання, яке може набуватись виключно завдяки безпосередній власній практичній діяльності [1, с. 421].

Важливим внеском в структуризацію поняття повсякдення $є$ праця П. Штомпки «У фокусі уваги повсякденного життя. Новий поворот в соціології», де автор розглядає повсякдення, як предмет дослідження «третьої науки». Польський соціолог вказує, що сучасні соціальні науки все більше відходять від аналізу мікропроцесів, пошуку концептуальних закономірностей розвитку суспільств в сторону соціальної екзистенції [8, 4 с.].

П. Штомпка, розглядаючи анатомію повсякденного життя, виділяє складові, які не являються повсякденням:

1. Повсякденне життя не обмежене «профральним» за Е. Дюркгаймом, а й належить до «священного». Тобто як типові повторювані дії, так і нетипові випадки в житті людини.

2. Повсякденне життя не обмежується соціальною реальністю широких мас населення, а й поширюється на політичних чи культурних лідерів.

3. Повсяқдення не виступає синонімом приватності [8, с. 5]. 


\section{Наукові записки ВДПУ ім. М.М. Кочюбинсъкого}

Третя теза $є$ однією з концептуальних для даної публікації. Оскільки в даній роботі ми не розглядаємо повсякдення, як рутинну, повторювальну дію. Більш цікавим для нас буде виступати нетипова поведінка науково-педагогічної інтелігенції в період Перебудови і це не слід вважати виходом за межі повсякдення.

Отже, в даній роботі ми намагались подати певні рамки розуміння повсякдення. I хоч цілі аналізу предмету повсякдення в поданих працях відрізняються, окреслення повсякдення накладаються одна на одну. Тому концептуальне розуміння повсякдення як перформативної дійсності може з легкістю перекочовувати із фрілософрії в історію та інші соціальні науки, ускладнюючи та доповнюючи існуюче знання.

Отже, в рамках даної статті було проаналізовано основні напрямки дослідження повсякдення в західній фрілософсько-історичній думці, трансформації уявлень, що дало можливість розширити коло історичних поглядів щодо його природи. В роботі Г. Зіммеля, песимістичне розуміння повсякдення, що узагальнює доробок фрілософрів починаючи з доби Відродження і аж до початку XX ст. Альтернативний погляд на повсякдення пропонують представники феноменології, які розуміють його як окреме, відмінне від інших фрорм, буття людської реальності, що виступає в ролі універсального смислу зі своїми унікальними ознаками. Представники прагматичної школи (Ч. Пірс та У. Джеймс) розуміють повсякденну діяльність, як сукупність осмислених та послідовних дій людини для досягнення певної мети. Д. Дьюї погоджується з представниками прагматичної школи, проте ускладнює їх модель розуміння людських дій її непередбачуваністю, сформованою необмеженою кількістю ймовірнісних факторів та умов. Особливу роль В дослідженні повсякдення слід приділити екзистенціоналістам, для яких останнє виступає не тільки в формі рутинних повторювальних процесів, але й переживання, невдачі та пристрасті: смерть, сором, страх, любов і т.д. Представник франкфуртської школи Е. Фромм у своїй праці «Мати чи бути?» розкриває крос культурні відмінності розуміння свого повсякденного життя в різних частинах світу. Натомість герменевтика пропонує розглядати повсякдення через призму взаємодій між поколіннями, а П. Штомпка пропонує систематизувати існуючі знання про повсякдення як предмет дослідження «третьої науки».

\section{ДЖЕРЕЛА ТА ЛІТЕРАТУРА:}

1. Гадамер Х.-Г. 13 Истина и метод: Основы философской герменевтики./ Пер. Б. Н. Бессонова. М.: Прогресс, 1988. 704 с.

2. Гуссерль Е. Криза європейських наук і трансцендентальна френоменологія. Вступ до френоменологічної філософрії // Філософрська думка. 2002. № 3. С. 134-149.

3. Еріх Фромм. Мати чи бути / Пер. 3 нім. О. Михайлова та А. Буряк. Київ: Український письменник, 2010. 222 с.

4. Зиммель Г. Избранные работы. Киев: Ника-Центр, 2006. 440 с.

5. Нечаев, С.Ю. Чарльз Пирс и пирсоведение в России. Опыт библиографиии / Вестн. Ленингр. гос. ун-та им. А. С. Пушкина. 2016. № 1. Т. 2. С. 25-35.

6. Станкевич Л. П., Полякова И. П. Феномен повседневности: сущность, содержание и целостность // Философия и общество. Москва, 2009. С. 72-81.

7. Хайдеггер, М. Время и бытие: Статьи и выступления. / Пер. В. В. Бибихина. Москва: Республика, 1993. 448 с.

8. Штомпка П. В фокусе внимания повседневная жизнь. Новый поворот в социологии // «Социологические исследования». 2009. №8. С. 3-13.

\section{Олег Коваль}

Винницкий государственный педагогический университет имени Михаила Коцюбинского, аспирант (Украина)

\section{Трансформация историко-философских представлений о повседневности в зарубежной историографии}

Аннотация. В данной статье обобщаются историко-фрилософрские подходы и их трансфоормации в рассмотрении повседневности в западной историографрии. Раскрывается важность понимания различий пессимистического, френоменологического, экзистенциального, прагматичного и инструментального, герменевтического и семантического, концепции социального становления. Отмечается важность роли данных подходов в становлении отечественной иколы исследования истории повседневности. Предлагается понимание трансформации представлений о повседневности через призму анализа основных работ в рамках данных научных трудов. 


\section{Серія: Iсторія. - 2019.- Bun. 28.}

Ключевые слова: повседневность, история повседневности, полипарадигмальность, феноменология, прагматизм, экзистенциализм, герменевтика, социальное становление.

\section{ABSTRACT}

\section{Oleh Koval}

Vinnytsia Mykhailo Kotsiubynskyi State Pedagogical University, postgraduate student(Ukraine)

\section{Transformation of historico-philosophical concepts of everyday life in international historiography}

The institutionalization of the history of everyday life, on the West and in the post-Soviet states, in particular in Ukraine, took place during historical breakthroughs when the dynamics of social transformations destroyed existing concepts of understanding of historico-political reality and the interpretation of accumulated data.

In this article the main directions of the study of everyday life in the Western philosophical and historical thought, transformation of conceptions and their transformation were analyzed, which made it possible to expand the range of historical views about its nature. Thus, more attention was paid to the following philosophical and historical trends: pessimistic, phenomenological, existential, pragmatic and instrumental, hermeneutic and semantic, and the concept of social formation of P. Sztompka. Thus, in the work of G. Simmel, the pessimistic understanding of everyday life summarizes the work of philosophers from the time of the Renaissance and up to the beginning of the $X X$ century. Representatives of phenomenology offer alternative way of understanding of everyday life: they see it as a separate, different from other forms, the existence of human reality in the role of universal meaning with its unique features. Representatives of the pragmatic school (Ch. Peirce and W. James) understand everyday life activities as a set of meaningful and consistent human actions for achieving a certain goal. J. Dewey agrees with them, however, at the same time he complicates their model of understanding human actions with its unpredictability, formed by an unlimited number of probabilistic factors and conditions. Special role in the study of everyday life was given to existentialists, who interpret everyday life not only as the form of routine repetitive processes, but also as feelings, failures and passions: death, shame, fear, love, etc. The representative of the Frankfurt school, E. Fromm, in his work, "To Have or To Be?" reveals the cross-cultural differences of understanding of everyday life in different parts of the world. Instead, hermeneutics suggests to consider everyday life through the prism of interactions between generations, and P. Sztompka proposes to systematize existing knowledge of everyday life as a subject of the "third science".

Key words: everyday life, the history of everyday life, poly-paradigmatic approach, phenomenology, pragmatism, existentialism, hermeneutics, social formation.

\section{REFERENCES:}

1. Gadamer Kh.-G. 13 Istina i metod: Osnovy filosofskoi germenevtiki./ Per. B. N. Bessonova. M.: Progress, 1988. $704 \mathrm{~s}$.

2. Ghusserlj E. Kryza jevropejsjkykh nauk i transcendentaljna fenomenologhija. Vstup do fenomenologhichnoji filosofiji // Filosofsjka dumka. 2002. № 3. S. 134-149.

3. Erikh Fromm. Maty chy buty / Per. z nim. O. Mykhajlova ta A. Burjak. Kyjiv: Ukrajinsjkyj pysjmennyk, 2010. $222 \mathrm{~s}$.

4. Zimmel G. Izbrannye raboty. Kiev: Nika-Tcentr, 2006. 440 s. (4).

5. Nechaev, S.lu. Charlz Pirs i pirsovedenie v Rossii. Opyt bibliografii // Vestn. Leningr. gos. un-ta im. A. S. Pushkina. 2016. № 1. T. 2. S. 25-35.

6. Stankevich L. P., Poliakova I.P. Fenomen povsednevnosti: sushchnost, soderzhanie i tcelostnost // Filosofiia i obshchestvo . Moskva, 2009. S. 72-81.

7. Khaĭdegger, M. Vremia i bytie: Stati i vystupleniia. / Per. V. V. Bibikhina Moskva: Respublika, 1993. $448 \mathrm{~s}$.

8. Shtompka P. V fokuse vnimaniia povsednevnaia zhizn. Novyi povorot $v$ sotciologii // «Sotciologicheskie issledovaniia». 2009. №8. S. 3-13.

Статтю подано до редколегії 27.03.2019 p. 